\title{
Anti-apoptotic and apoptotic pathway analysis of arsenic trioxide-induced apoptosis in human gastric cancer SGC-7901 cells
}

\author{
YAO YU*, YU YANG and JING WANG* \\ Department of Oncology, The Second Affiliated Hospital of Harbin Medical University, \\ Harbin, Heilongjiang 150086, P.R. China
}

Received March 13, 2014; Accepted May 28, 2014

DOI: $10.3892 /$ or.2014.3276

\begin{abstract}
The present study aimed to investigate the effect of arsenic trioxide $\left(\mathrm{As}_{2} \mathrm{O}_{3}\right)$ on human gastric cancer SGC-7901 cells. SGC-7901 cells were treated with different concentrations of $\mathrm{As}_{2} \mathrm{O}_{3}$ in the cell growth media for 24, 48 and $72 \mathrm{~h}$, and the growth rates were determined by WST-1 cell proliferation assays. Analyses of nuclear morphological changes were performed with DAPI fluorescence staining. Cell apoptosis rates as assessed by flow cytometry were determined after cells were grown in media for $48 \mathrm{~h}$ containing different $\mathrm{As}_{2} \mathrm{O}_{3}$ concentrations. The protein expression patterns of the apoptosis factors, Bax, Fas and caspase-8, and anti-apoptosis factors, Akt, p-Akt, mTOR and p-mTOR, were evaluated by western blot analysis following treatment of the cells with different $\mathrm{As}_{2} \mathrm{O}_{3}$ concentrations in the cell growth media for $48 \mathrm{~h}$. As a result, $\mathrm{As}_{2} \mathrm{O}_{3}$ inhibited the growth of human gastric cancer SGC-7901 cells in concentrations $>5 \mu \mathrm{mol} / 1$ for longer than $24 \mathrm{~h}$. Flow cytometric analysis revealed that the apoptosis of SGC-7901 cells occurred in an $\mathrm{As}_{2} \mathrm{O}_{3}$ concentration-dependent manner after $48 \mathrm{~h}(\mathrm{P}<0.001)$. Expression levels of $\mathrm{Bax}$, Fas and caspase- 8 were increased, whereas expression levels of Akt, p-Akt, mTOR and p-mTOR were decreased in the SGC-7901 cells after a 48-h incubation with different $\mathrm{As}_{2} \mathrm{O}_{3}$ concentrations. In conclusion, $\mathrm{As}_{2} \mathrm{O}_{3}$ induced human gastric cancer SGC-7901 cell apoptosis in a time- and concentration dependent manner by inhibiting the activity of anti-apoptosisrelated factors.
\end{abstract}

Correspondence to: Professor Yu Yang, Department of Oncology, The Second Affiliated Hospital of Harbin Medical University, 246 Xuefu Road, Harbin 150086, P.R. China

E-mail: yangyu031114@163.com

${ }^{*}$ Contributed equally

Key words: arsenic trioxide, stomach neoplasms, anti-apoptosis proteins, apoptosis

\section{Introduction}

Gastric carcinoma (GC) remains the third leading cause of cancer-related mortality in men worldwide (1). To date, there are few effective clinical treatments for this highly malignant tumor, and conventional adjuvant treatments have limited effects on the survival of patients with advanced gastric cancer (2). Much research has been conducted to identify efficient chemotherapeutic agents for the cure and prevention of GC, and recently apoptosis has been shown to play a significant role in the treatment of GC cells.

Arsenic trioxide $\left(\mathrm{As}_{2} \mathrm{O}_{3}\right)$ is an arsenic compound that has been used as a medicinal agent for more than 2400 years (3). In the 1970s, Chinese researchers were the first to discover its ability to cure acute promyelocytic leukemia (APL) (4). Since then other research groups have demonstrated worldwide that $\mathrm{As}_{2} \mathrm{O}_{3}$ also inhibits the growth of various solid tumors, including esophageal carcinoma $(5,6)$, breast $(3,7,8)$, bladder (9), lung (10) and liver cancer (11), multiple myeloma (12), neuroblastoma (13), colon (14) and ovarian cancer (15). It has been shown that $\mathrm{As}_{2} \mathrm{O}_{3}$ regulates proliferation, invasion, differentiation, angiogenesis and apoptosis of cancer cells (16). However, the precise mechanism of $\mathrm{As}_{2} \mathrm{O}_{3}$-related apoptosis induction of cancer cells is not fully understood. Recent experiments confirm that $\mathrm{As}_{2} \mathrm{O}_{3}$ affects the activities of protein kinase $\mathrm{B}(\mathrm{Akt})$, c-Jun N-terminal kinases (JNK), nuclear factor $\kappa \mathrm{B}(\mathrm{NF}-\kappa \mathrm{B})$, glutathione and calcium signaling, reactive oxygen species (ROS), caspases, as well as pro- and anti-apoptotic proteins (17-20). It was noted that $\mathrm{As}_{2} \mathrm{O}_{3}$ can reduce the activation of the $\mathrm{Akt} / \mathrm{mTOR}$ pathway by reducing Akt, p70S6K and rpS6 phosphorylation in human leukemia cells (21). The PI3K/Akt/mTOR pathway is a crucial regulatory cascade that is central to a variety of physiological functions, including cell cycle regulation, survival, protein synthesis, metabolism, motility, apoptosis, proliferation and angiogenesis $(22,23)$. The phosphoinositide 3-kinase (PI3K) activates Akt, a serine/threonine kinase, which phosphorylates the mammalian target of rapamycin (mTOR) repressor tuberous sclerosis complex 2 (24), which in turn activates mTOR downregulation of autophagy inducing autophagy-related (Atg) proteins $(25,26)$. Recently it has been demonstrated that $\mathrm{As}_{2} \mathrm{O}_{3}$ suppresses PI3K/Akt activity and induces JNK activa- 
tion thereby enhancing chronic B-lymphocytic leukemia cell apoptosis (27).

The major apoptosis pathways are the extrinsic pathways (death receptor) and intrinsic pathways (mitochondrial) (28). The common effector for extrinsic apoptotic pathway initiation is FASL, which regulates apoptosis via binding to FASR, a member of the tumor necrosis factor (TNF) receptor family of proteins. Deregulation of the FAS pathway has been implicated in various malignancies and diseases (29). After stimulation of the death receptor pathway by the FAS ligand, conformational changes to the FAS receptor lead to cleavage of pro-caspase 8 into its activated form, which then cleaves other effector caspases eventually leading to apoptosis. During the apoptotic process, Bcl-2-associated X (Bax) inhibits the anti-apoptotic B-cell lymphoma 2 (Bcl-2) protein (30) and permeabilizes the mitochondrial outer membrane, leading to cytochrome $c$ release (31).

In the present study, we explored the effects of $\mathrm{As}_{2} \mathrm{O}_{3}$ on expression levels of FAS, caspase- 8 and Bax proteins in human gastric cancer SGC-7901 cells. Then we further analyzed the role of $\mathrm{As}_{2} \mathrm{O}_{3}$ in the $\mathrm{Akt} / \mathrm{mTOR}$ pathway in $\mathrm{As}_{2} \mathrm{O}_{3}$-exposed cells.

\section{Materials and methods}

Materials. $\mathrm{As}_{2} \mathrm{O}_{3}$ solution was purchased from YiDa Pharmacy. The stock solution of arsenic trioxide was $8 \mathrm{mM}$ and was stored at $4^{\circ} \mathrm{C}$. RPMI-1640 medium and FBS were purchased from Hyclone. Anti-Akt polyclonal antibodies (9272) were purchased from Cell Signaling Technology. Antiphospho-Akt (s473), anti-mTOR, anti-phospho-mTOR (s2448), anti-Bax, anti-caspase- 8 and anti-FAS polyclonal antibodies were purchased from ImmunoWay. Anti- $\beta$-actin monoclonal, goat anti-mouse and goat anti-rabbit secondary antibodies conjugated to horseradish peroxidase were purchased from Santa Cruz Biotechnology.

Cell culture and treatment. Human SGC-7901 gastric cancer cells were cultured in RPMI-1640 medium containing 10\% FBS in a $5 \% \mathrm{CO}_{2}$ humidified atmosphere chamber at $37^{\circ} \mathrm{C}$. For the experiments, FBS was reduced to $2 \%$, and exponentially growing cells were incubated for the indicated time periods with different concentrations of $\mathrm{As}_{2} \mathrm{O}_{3}(0,2.5,5,7.5,10,12.5$ and $15 \mu \mathrm{mol} / \mathrm{l})$.

WST-1 proliferation assay. The effect of $\mathrm{As}_{2} \mathrm{O}_{3}$ on in vitro growth inhibition of SGC-7901 cells was measured using the WST-1 Cell Proliferation and Cytotoxicity Assay Kit (Beyotime Institute of Biotechnology) according to the manufacturer's protocol. SGC-7901 cells were seeded in 96-well plates at a density of $1.0 \times 10^{4}$ cells per well in $200 \mu \mathrm{l}$ RPMI-1640 medium containing 10\% FBS for $24 \mathrm{~h}$. Then the cells were exposed to different concentrations of $\mathrm{As}_{2} \mathrm{O}_{3}(0$, $2.5,5,7.5,10,12.5$ and $15 \mu \mathrm{mol} / \mathrm{l})$ in RPMI-1640 medium containing $2 \%$ FBS for 24,48 and $72 \mathrm{~h}$. Finally $20 \mu \mathrm{l}$ of WST-1 solution was added to each well, and the cells were incubated for another $1 \mathrm{~h}$. The absorbance at $450 \mathrm{~nm}$ was measured using a microplate reader (Finnpipette MK3 Multiskan). The amount of the formazan dye, which is generated by activities of dehydrogenases in the cells, is proportional to the number of

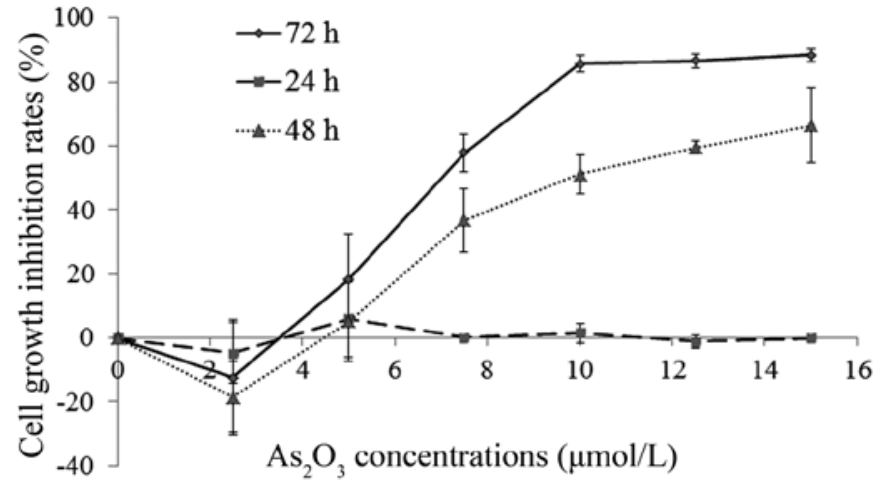

Figure 1. Cell growth inhibitory effects of arsenic trioxide $(0,2.5,5,7.5,10$, 12.5 and $15 \mu \mathrm{mol} / 1)$ on SGC-7901 cells after a $24-, 48-$ and $72-\mathrm{h}$ incubation.

living cells. Inhibitory rates of cellular growth were calculated with the following formula: Inhibitory rate $(\%)=(1-$ A value of experimental group/A value in the control group) $\mathrm{x} 100 \%$. The $0 \mu \mathrm{mol} / 1$ group was used as the control group. A graph with inhibitory cell growth rates (y-axis) against the concentrations of $\mathrm{As}_{2} \mathrm{O}_{3}$ (x-axis) was plotted.

Analysis of nuclear morphology by DAPI staining. Apoptosis was assessed based on changes in the nuclear morphology by staining the cells with the fluorescent DNA dye 4',6-diamidino2'-phenylindole dihydrochloride (DAPI) (Roche). Briefly, cells were treated with $\mathrm{As}_{2} \mathrm{O}_{3}(0$ and $10 \mu \mathrm{mol} / \mathrm{l})$ in RPMI1640 medium containing $2 \%$ FBS for $48 \mathrm{~h}$. Then the cells were washed with PBS and incubated with $1 \mu \mathrm{g} / \mathrm{ml}$ DAPI in methanol for $30 \mathrm{~min}$ at $37^{\circ} \mathrm{C}$ in darkness. Slides were viewed using a fluorescence microscope with ultraviolet (UV) excitation at $300-500 \mathrm{~nm}$. Cells were evaluated as normal or apoptotic depending on morphological characteristics. Normal nuclei (smooth nuclei) and apoptotic nuclei (condensed or fragmented chromatin) were observed.

Analysis of apoptosis. Cells were treated with different concentrations of $\mathrm{As}_{2} \mathrm{O}_{3}(0,7.5,10,12.5$ and $15 \mu \mathrm{mol} / \mathrm{l})$ in 2\% FBS and RPMI-1640 for $48 \mathrm{~h}$, collected and then stained using the Annexin V-FITC Apoptosis Detection Kit I (BD Biosciences) for flow cytometric analyses. The $0 \mu \mathrm{mol} / 1$ group served as the control.

Protein extraction and western blot analysis. Cells were treated with different concentrations of $\mathrm{As}_{2} \mathrm{O}_{3}(0,5,7.5,10$, 12.5 and $15 \mu \mathrm{mol} / \mathrm{l}$ ) in $2 \% \mathrm{FBS}$ and RPMI-1640 medium for $48 \mathrm{~h}$. Both adherent and floating cells were harvested and lysed with RIPA lysis buffer and phenylmethanesulfonyl fluoride (Beyotime Institute of Biotechnology), incubated at $4^{\circ} \mathrm{C}$ for $40 \mathrm{~min}$ and centrifuged for $10 \mathrm{~min}$ at $12,000 \mathrm{rpm}$. Total protein in the cell lysate was measured with an enhanced BCA protein assay kit (Beyotime Institute of Biotechnology). For western blot analysis, equal amounts of protein were separated by SDS-PAGE and then transferred onto PVDF membranes (Millipore). The membranes were blocked for $1.5 \mathrm{~h}$ in a non-fat dried milk solution containing 1\% Tween-20. The membranes were then incubated with primary antibodies for $\beta$-actin (1:800), Akt (1:800), p-Akt (1:800), mTOR (1:800), 

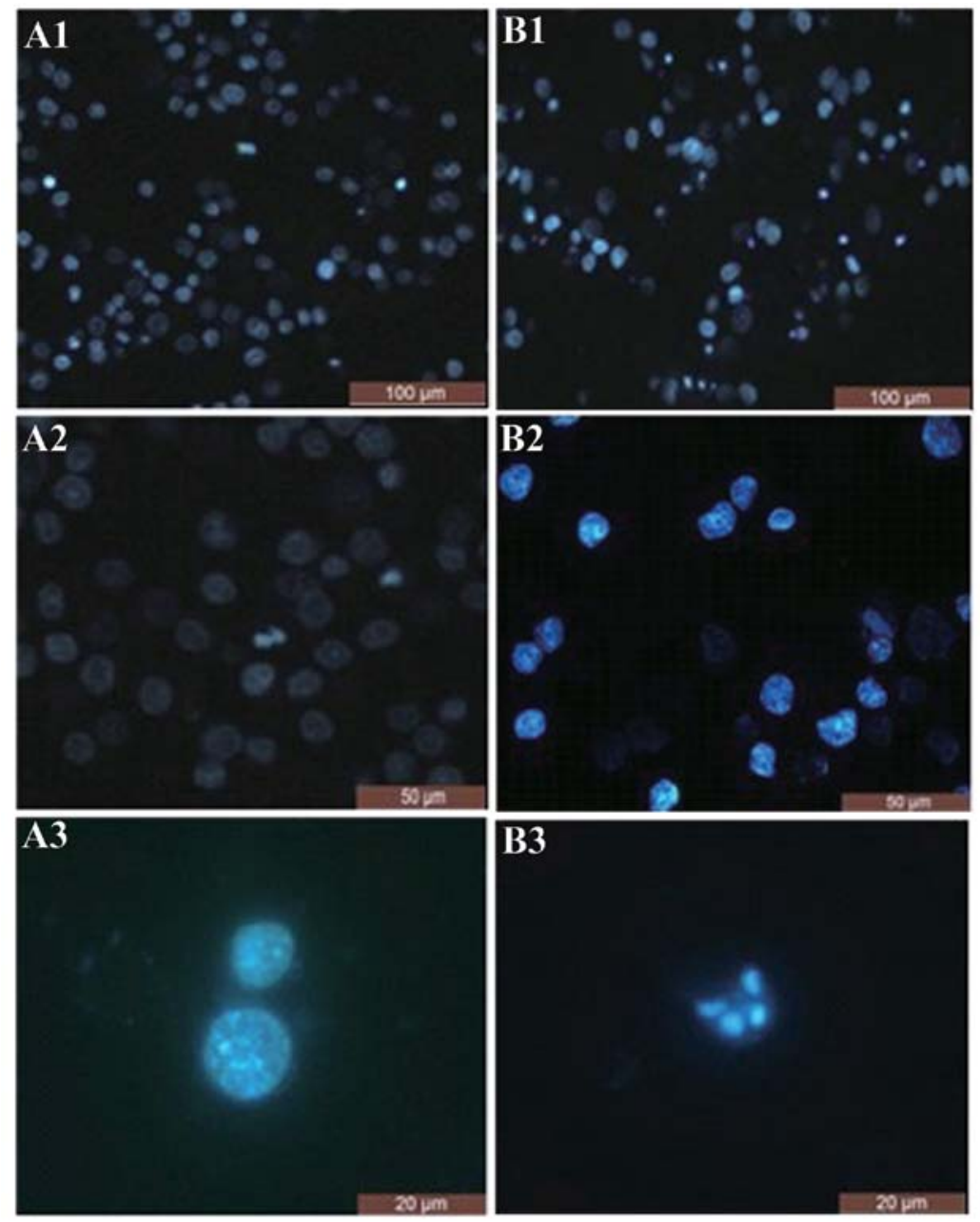

Figure 2. Changes in SGC-7901 cell nuclear morphology visualized with DAPI under a fluorescence microscope. (A1-A3) Control group after 48 h. (B1B3) Cells after exposure to $10 \mu \mathrm{mol} / 1 \mathrm{As}_{2} \mathrm{O}_{3}$ for $48 \mathrm{~h}$.

p-mTOR (1:800), Bax (1:1000), caspase-8 (1:1000) and FAS (1:1000) overnight at $4^{\circ} \mathrm{C}$, followed by incubation with anti-mouse or anti-rabbit (1:5000) secondary antibodies for $1 \mathrm{~h}$. Finally, protein bands were detected using a chemiluminescent substrate (HRP) kit (Beyotime Institute of Biotechnology). The $\beta$-actin level was used as an internal standard.

Statistical analyses. All experiments were performed at least three times. Data for each series of experiments (performed in triplicates) are expressed as the mean values \pm standard deviation of the mean (SD). Statistical significance of differences between groups was analyzed using ANOVA analysis. $\mathrm{P}<0.05$ was considered to indicate a statistically significant difference.

\section{Results}

Extended incubation with $\mathrm{As}_{2} \mathrm{O}_{3}$ leads to cell growth inhibition. Human SGC-7901 gastric cancer cells were incubated with different concentrations of $\mathrm{As}_{2} \mathrm{O}_{3}(0,2.5,5,7.5,10,12.5$ and $15 \mu \mathrm{mol} / \mathrm{l})$ for 24,48 and $72 \mathrm{~h}$ and the cell growth inhibition was recorded using the WST- 1 assay. When the $\mathrm{As}_{2} \mathrm{O}_{3}$ solution concentrations were $>5 \mu \mathrm{mol} / 1$, the cell growth was significantly reduced after 48 and 72 -h incubation periods, whereas after a 24-h incubation none of the $\mathrm{As}_{2} \mathrm{O}_{3}$ concentra- tions had an effect on cell growth. Concentrations $<5 \mu \mathrm{mol} / 1$ led to reduced growth inhibition (Fig. 1).

\section{$\mathrm{As}_{2} \mathrm{O}_{3}$ leads to apoptosis of SGC-7901 cells}

Analysis of nuclear morphology as assessed by DAPI staining. The SGC-7901 cells were treated with $10 \mu \mathrm{mol} / 1 \mathrm{As}_{2} \mathrm{O}_{3}$ for $48 \mathrm{~h}$, and apoptosis was visualized by DAPI staining using fluorescence microscopy. Compared with the control, a large number of cells displayed morphological changes exhibiting the typical characteristics of apoptotic cell death, including cell shrinkage, chromatin condensation, chromatin crescent formation/margination, DNA fragmentation and apoptotic body formation (Fig. 2).

Analysis of apoptosis by flow cytometry. With increasing concentrations $(0,7.5,10,12.5$ and $15 \mu \mathrm{mol} / \mathrm{l})$ of $\mathrm{As}_{2} \mathrm{O}_{3}$ in the growth media, the apoptosis rates increased after $48 \mathrm{~h}$ from $2.83 \pm 0.88,9.85 \pm 2.18,25.81 \pm 2.17$ and $29.92 \pm 3.30$ to $35.40 \pm 0.58 \%$, which indicated that $\mathrm{As}_{2} \mathrm{O}_{3}$ induced the apoptosis of human gastric cancer SGC-7901 cells in a dosedependent manner (Fig. 3).

Protein extraction and western blot analysis $\mathrm{As}_{2} \mathrm{O}_{3}$ induces Bax, Fas and caspase- 8 activation. SGC-7901 cells were incubated with different $\mathrm{As}_{2} \mathrm{O}_{3}$ concentrations 


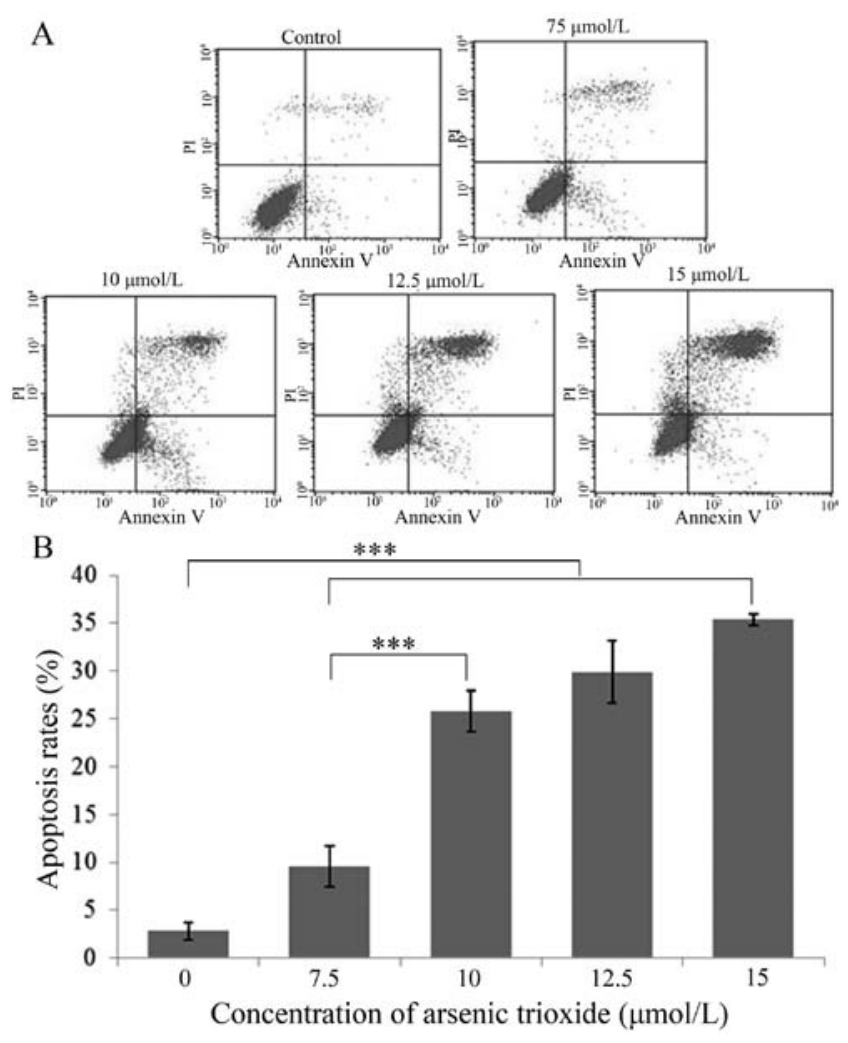

Figure 3. Apoptosis rates of the SGC-7901 cells following addition of $\mathrm{As}_{2} \mathrm{O}_{3}$ $(0,7.5,10,12.5$ and $15 \mu \mathrm{mol} / \mathrm{l})$ to the medium for $48 \mathrm{~h}$. (A) Representative flow cytometric images. (B) Histogram of the data derived from the flow cytometric analyses $(n=3) .{ }^{* * *} \mathrm{P}<0.001$.
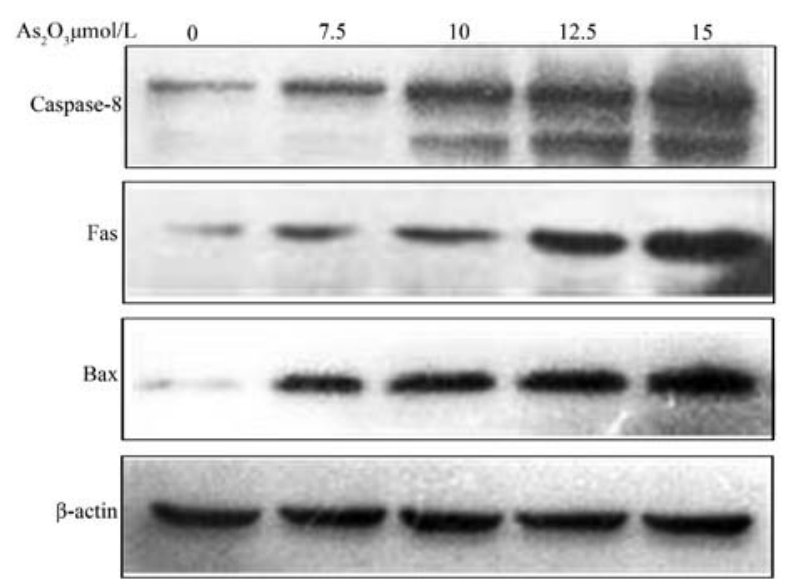

Figure 4. Effect of $\mathrm{As}_{2} \mathrm{O}_{3}$ concentrations (0, 7.5, 10, 12.5 and $\left.15 \mu \mathrm{mol} / \mathrm{l}\right)$ on protein expression levels of Bax, Fas and caspase-8 in SGC-7901 cells after a 48-h incubation.

$(0,7.5,10,12.5$ and $15 \mu \mathrm{mol} / \mathrm{l})$ for $48 \mathrm{~h}$, and then Bax, Fas and caspase- 8 protein expression levels were analyzed via western blotting. As shown in Fig. 4, expresssion of Bax, Fas and caspase- 8 protein was increased with increasing $\mathrm{As}_{2} \mathrm{O}_{3}$ concentrations.

$\mathrm{As}_{2} \mathrm{O}_{3}$ suppresses Akt, $p$-Akt, mTOR and p-mTOR activation. SGC-7901 cells were incubated with different $\mathrm{As}_{2} \mathrm{O}_{3}$ concentrations $(0,7.5,10,12.5$ and $15 \mu \mathrm{mol} / \mathrm{l})$ for $48 \mathrm{~h}$ and Akt, p-Akt, mTOR and p-mTOR protein expression levels were analyzed

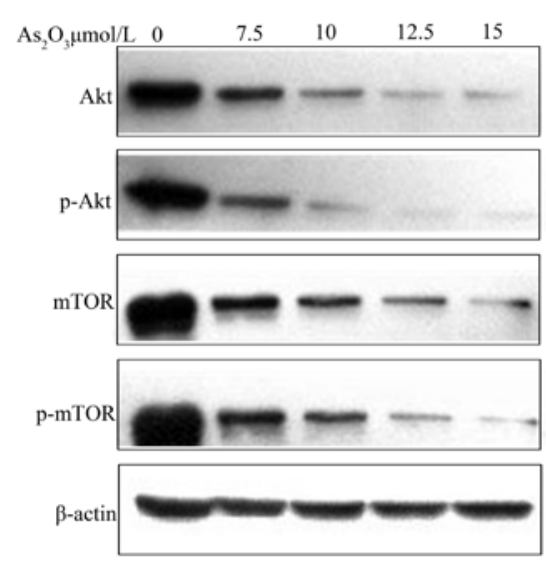

Figure 5. Effect of $\mathrm{As}_{2} \mathrm{O}_{3}$ concentrations $(0,7.5,10,12.5$ and $15 \mu \mathrm{mol} / \mathrm{l})$ on protein expression levels of Akt, p-Akt, mTOR, p-mTOR in SGC-7901 cells after a 48-h incubation.

via western blotting. As shown in Fig. 5, Akt, p-Akt, mTOR and p-mTOR protein expression levels decreased with increasing $\mathrm{As}_{2} \mathrm{O}_{3}$ concentrations.

\section{Discussion}

In the present study, we demonstrated that $\mathrm{As}_{2} \mathrm{O}_{3}$ induced the apoptosis of human gastric cancer SGC-7901 cells in a dose- and time-dependent manner, which is in agreement with previous findings of the $\mathrm{As}_{2} \mathrm{O}_{3}$-triggered apoptosis of lung cancer cells (32).

Further analyses revealed that the apoptotic proteins Bax, Fas and caspase- 8 were upregulated and the anti-apoptotic proteins Akt, p-Akt, mTOR as well as phosphorylated mTOR (p-mTOR) were downregulated. The PI3K (phosphatidylinositol 3 kinase) pathway is a signal transduction cascade, which is at the center of many physiological functions including cell cycle regulation, cell survival, protein synthesis, metabolism as well as blood vessel formation. There are two key elements (Akt and mTOR) in the PI3K transduction pathway. Akt (serine/threonine kinase) is the regulator of the PI3K transduction pathways by regulating a variety of downstream effectors. A variety of growth factors, cytokines and hormones lead to the phosphorylation of Akt, which in turn activates downstream effectors including mTOR directly or indirectly by preventing the combination of mTORC 1 and mTORC 2 thereby promoting protein synthesis and cell growth $(33,34)$. Akt also inactivates cell cycle inhibitors (p21 and p27) and promotes cell cycle proteins (c-Myc and cyclinD1) to maintain cell survival $(35,36)$. Another study found that Akt suppressed the apoptosis inhibition genes (BIM and BAD) and reduced the expression of the tumor-suppressor protein (p53) restricting programmed cell death and promoting cell survival (37). Our results showed that $\mathrm{As}_{2} \mathrm{O}_{3}$ concentrations $<5 \mu \mathrm{mol} / 1$ promoted cell growth and during the 24-h incubation cell growth was not inhibited by any $\mathrm{As}_{2} \mathrm{O}_{3}$ concentration (Fig. 1). In previous studies, the apoptotic effect of $\mathrm{As}_{2} \mathrm{O}_{3}$ was attributed to reactive oxygen species development $(38,39)$, and $\mathrm{As}_{2} \mathrm{O}_{3}$ has also been shown to inhibit mitochondrial respiration, thereby enhancing ROS occurrence (40), which has been used to sensitize tumor cells for radiation therapy (41). Autophagy constitutes a stress 
adaptation that avoids cell death, and cells can compensate oxidative stress damages to a certain extent through autophagy, which was demonstrated by different cell reactions upon low and high dosage exposures to safingol, which is a ROS inducer (42). Autophagy following $\mathrm{As}_{2} \mathrm{O}_{3}$ exposure has also been reported (43). We suggest that at low doses of $\mathrm{As}_{2} \mathrm{O}_{3}$ up to $5 \mu \mathrm{mol} / 1$, autophagy is the main mechanism triggered in SGC-7901 cells and apoptosis is blocked (44) leading to somewhat reduced growth inhibition. Moreover, in short periods ( $24 \mathrm{~h})$, the ROS development is under the threshold for inducing apoptosis, probably also due to oxygen radical squelching mechanisms (45). This is supported by the finding that apoptotic effects of $\mathrm{As}_{2} \mathrm{O}_{3}$ are most pronounced in tumor cells with low GSH levels, and ascorbic acid could further enhance its capacity for apoptosis induction (45).

A drawback of our study was that apoptotic mechanisms are complex and this study is a preliminary study of the Akt/ mTOR anti-apoptotic pathway, while other anti-apoptosis pathways need further investigation. In addition, the effective dose of $\mathrm{As}_{2} \mathrm{O}_{3}$ was $>5 \mu \mathrm{mol} / 1$, which is higher than the allowed clinical therapeutic dose of 1-2 $\mu \mathrm{mol} / 1$, thus further long-term and sensitizing agent evaluations are warranted (45).

In conclusion, our in vitro results showed that $\mathrm{As}_{2} \mathrm{O}_{3}$ can induce apoptosis in human gastric cancer SGC-7901 cells. $\mathrm{As}_{2} \mathrm{O}_{3}$ treatment led to enhanced expression of the apoptotic proteins Bax, Fas and caspase-8, and reduced the expression of the anti-apoptotic proteins Akt and mTOR as well as their phosphorylated forms p-Akt and p-mTOR in a time- and dose- dependent manner. Since the effective dose of $\mathrm{As}_{2} \mathrm{O}_{3}$ was higher than the therapeutic limit and growth inhibition rate reductions were incubation time-dependent, further research is necessary to establish $\mathrm{As}_{2} \mathrm{O}_{3}$ for the treatment of gastric cancers.

\section{Acknowledgements}

We thank Xuguang Zhang for the help and support. This work was supported by grants from the Heilongjiang Province Natural Science Fund Project (D200862).

\section{References}

1. Jemal A, Bray F, Center MM, Ferlay J, Ward E and Forman D: Global cancer statistics. CA Cancer J Clin 61: 69-90, 2011.

2. Lim L, Michael M, Mann GB and Leong T: Adjuvant therapy in gastric cancer. J Clin Oncol 23: 6220-6232, 2005.

3. Wang Y, Zhang Y, Yang L, et al: Arsenic trioxide induces the apoptosis of human breast cancer MCF-7 cells through activation of caspase-3 and inhibition of HERG channels. Exp Ther Med 2: 481-486, 2011.

4. Zhou J: Arsenic trioxide: an ancient drug revived. Chin Med J 125: 3556-3560, 2012.

5. Shen ZY, Shen J, Cai WJ, Hong C and Zheng MH: The alteration of mitochondria is an early event of arsenic trioxide induced apoptosis in esophageal carcinoma cells. Int J Mol Med 5: $155-158,2000$.

6. Shen ZY, Zhang Y, Chen JY, et al: Intratumoral injection of arsenic to enhance antitumor efficacy in human esophageal carcinoma cell xenografts. Oncol Rep 11: 155-159, 2004.

7. Chow SK, Chan JY and Fung KP: Inhibition of cell proliferation and the action mechanisms of arsenic trioxide $\left(\mathrm{As}_{2} \mathrm{O}_{3}\right)$ on human breast cancer cells. J Cell Biochem 93: 173-187, 2004.

8. Ye J, Li A, Liu Q, Wang X and Zhou J: Inhibition of mitogenactivated protein kinase enhances apoptosis induced by arsenic trioxide in human breast cancer MCF-7 cells. Clin Exp Pharmacol Physiol 32: 1042-1048, 2005.
9. Jutooru I, Chadalapaka G, Sreevalsan S, et al: Arsenic trioxide downregulates specificity protein $(\mathrm{Sp})$ transcription factors and inhibits bladder cancer cell and tumor growth. Exp Cell Res 316: 2174-2188, 2010

10. Chien CW, Yao JH, Chang SY, Lee PC and Lee TC: Enhanced suppression of tumor growth by concomitant treatment of human lung cancer cells with suberoylanilide hydroxamic acid and arsenic trioxide. Toxicol Appl Pharmacol 257: 59-66, 2011.

11. Li H, Gong J, Jiang X and Shao H: Arsenic trioxide treatment of rabbit liver VX-2 carcinoma via hepatic arterial cannulationinduced apoptosis and decreased levels of survivin in the tumor tissue. Croat Med J 54: 12-16, 2013.

12. Matulis SM, Morales AA, Yehiayan L, Lee KP, Cai Y and Boise LH: Alterations in glutathione levels and apoptotic regulators are associated with acquisition of arsenic trioxide resistance in multiple myeloma. PloS One 7: e52662, 2012.

13. Ora I, Bondesson L, Jonsson C, et al: Arsenic trioxide inhibits neuroblastoma growth in vivo and promotes apoptotic cell death in vitro. Biochem Biophys Res Commun 277: 179-185, 2000.

14. Nakagawa Y, Akao Y, Morikawa H, et al: Arsenic trioxideinduced apoptosis through oxidative stress in cells of colon cancer cell lines. Life Sci 70: 2253-2269, 2002.

15. Bornstein J, Sagi S, Haj A, Harroch J and Fares F: Arsenic trioxide inhibits the growth of human ovarian carcinoma cell line. Gynecol Oncol 99: 726-729, 2005.

16. Liu Y, Zhang W, Zhang X, Qi Y, Huang D and Zhang Y: Arsenic trioxide inhibits invasion/migration in SGC-7901 cells by activating the reactive oxygen species-dependent cyclooxygenase-2/ matrix metalloproteinase-2 pathway. Exp Biol Med 236: 592-597, 2011.

17. Bowling BD, Doudican N, Manga P and Orlow SJ: Inhibition of mitochondrial protein translation sensitizes melanoma cells to arsenic trioxide cytotoxicity via a reactive oxygen species dependent mechanism. Cancer Chemother Pharmacol 63: 37-43, 2008.

18. Florea AM and Büsselberg D: Anti-cancer drugs interfere with intracellular calcium signaling. Neurotoxicology 30: 803-810, 2009.

19. Gao F, Yi J, Shi GY, Li H, Shi XG and Tang XM: The sensitivity of digestive tract tumor cells to $\mathrm{As}_{2} \mathrm{O}_{3}$ is associated with the inherent cellular level of reactive oxygen species. World J Gastroenterol 8: 36-39, 2002.

20. Izdebska M, Grzanka A, Szczepanski MA and Litwiniec A: Selected mechanisms of the therapeutic effect of arsenic trioxide in cancer treatment. Postepy Hig Med Dosw 62: 463-467, 2008 (In Polish).

21. Calvino E, Estan MC, Simon GP, et al: Increased apoptotic efficacy of lonidamine plus arsenic trioxide combination in human leukemia cells. Reactive oxygen species generation and defensive protein kinase (MEK/ERK, Akt/mTOR) modulation. Biochem Pharmacol 82: 1619-1629, 2011.

22. Carracedo A and Pandolfi PP: The PTEN-PI3K pathway: of feedbacks and cross-talks. Oncogene 27: 5527-5541, 2008.

23. Markman B, Dienstmann R and Tabernero J: Targeting the $\mathrm{PI} 3 \mathrm{~K} / \mathrm{Akt} / \mathrm{mTOR}$ pathway - beyond rapalogs. Oncotarget 1: 530-543, 2010.

24. Hay N: The Akt-mTOR tango and its relevance to cancer. Cancer Cell 8: 179-183, 2005.

25. He C and Klionsky DJ: Regulation mechanisms and signaling pathways of autophagy. Annu Rev Genet 43: 67-93, 2009.

26. Meijer AJ and Codogno P: Regulation and role of autophagy in mammalian cells. Int J Biochem Cell Biol 36: 2445-2462, 2004.

27. Redondo-Munoz J, Escobar-Diaz E, Hernandez Del Cerro M, et al: Induction of B-chronic lymphocytic leukemia cell apoptosis by arsenic trioxide involves suppression of the phosphoinositide 3-kinase/Akt survival pathway via c-jun-NH2 terminal kinase activation and PTEN upregulation. Clin Cancer Res 16: 4382-4391, 2010.

28. Ghobrial IM, Witzig TE and Adjei AA: Targeting apoptosis pathways in cancer therapy. CA Cancer J Clin 55: 178-194, 2005.

29. Komarov AP, Rokhlin OW, Yu CA and Gudkov AV: Functional genetic screening reveals the role of mitochondrial cytochrome $b$ as a mediator of FAS-induced apoptosis. Proc Natl Acad Sci USA 105: 14453-14458, 2008.

30. Oltvai ZN, Milliman CL and Korsmeyer SJ: Bcl-2 heterodimerizes in vivo with a conserved homolog, Bax, that accelerates programmed cell death. Cell 74: 609-619, 1993.

31. Suen DF, Norris KL and Youle RJ: Mitochondrial dynamics and apoptosis. Genes Dev 22: 1577-1590, 2008. 
32. Han B, Zhou G, Zhang Q, et al: Effect of arsenic trioxide (ATO) on human lung carcinoma PG cell line: ATO induced apoptosis of PG cells and decreased expression of Bcl-2, Pgp. J Exp Ther Oncol 4: 335-342, 2004

33. Guertin DA and Sabatini DM: Defining the role of mTOR in cancer. Cancer Cell 12: 9-22, 2007.

34. Sarbassov DD, Guertin DA, Ali SM and Sabatini DM: Phosphorylation and regulation of Akt/PKB by the rictor-mTOR complex. Science 307: 1098-1101, 2005.

35. Brunet A, Bonni A,Zigmond MJ et al: Akt promotes cell survival by phosphorylating and inhibiting a Forkhead transcription factor. Cell 96: 857-868, 1999.

36. Diehl JA, Cheng M, Roussel MF and Sherr CJ: Glycogen synthase kinase-3beta regulates cyclin D1 proteolysis and subcellular localization. Genes Dev 12: 3499-3511, 1998.

37. Engelman JA, Luo J and Cantley LC: The evolution of phosphatidylinositol 3-kinases as regulators of growth and metabolism. Nat Rev Genet 7: 606-619, 2006.

38. Chen YC, Lin-Shiau SY and Lin JK: Involvement of reactive oxygen species and caspase 3 activation in arsenite-induced apoptosis. J Cell Physiol 177: 324-333, 1998.

39. Woo SH, Park IC, Park MJ, et al: Arsenic trioxide induces apoptosis through a reactive oxygen species-dependent pathway and loss of mitochondrial membrane potential in HeLa cells. Int J Oncol 21: 57-63, 2002.
40. Pelicano H, Feng L, Zhou Y, et al: Inhibition of mitochondrial respiration: a novel strategy to enhance drug-induced apoptosis in human leukemia cells by a reactive oxygen species-mediated mechanism. J Biol Chem 278: 37832-37839, 2003.

41. Diepart C, Karroum O, Magat J, et al: Arsenic trioxide treatment decreases the oxygen consumption rate of tumor cells and radiosensitizes solid tumors. Cancer Res 72: 482-490, 2012.

42. Ling LU, Tan KB, Lin H and Chiu GN: The role of reactive oxygen species and autophagy in safingol-induced cell death. Cell Death Dis 2: e129, 2011.

43. Zhang G, Liu J, Zhang Y, et al: Cbl-b-dependent degradation of FLIP(L) is involved in ATO-induced autophagy in leukemic K562 and gastric cancer cells. FEBS Lett 586: 3104-3110, 2012.

44. Cheng Y, Qiu F, Ye YC, et al: Autophagy inhibits reactive oxygen species-mediated apoptosis via activating p38-nuclear factor-kappa B survival pathways in oridonin-treated murine fibrosarcoma L929 cells. FEBS J 276: 1291-1306, 2009.

45. Dai J, Weinberg RS, Waxman S and Jing Y: Malignant cells can be sensitized to undergo growth inhibition and apoptosis by arsenic trioxide through modulation of the glutathione redox system. Blood 93: 268-277, 1999. 